\title{
High performance mortar may help to reduce damages in masonry constructions for seismic areas in Mexico
}

\author{
J. Gomez-Dominguez \& L. A. Badillo \\ Monterrey TEC, Monterrey Campus, Mexico
}

\begin{abstract}
Seismicity is a great concern in Mexico and other Latin-American countries, particularly low income construction houses and small masonry buildings suffer considerable damages under earthquakes. This work describes a practical research for developing and testing at the laboratory stage an optimal high performance mortar in small masonry sections under loads. Results showed that masonry sections made with the high performance mortar were $34.65 \%$ stronger in compression than sections made with conventional mortar; on the other hand masonry sections tested under diagonal compression were $11.91 \%$ stronger. A simplified seismic analysis carried out on three story buildings located in Mexico City showed that the lower story for the conventional masonry building would not comply with its code, while the building with high performance mortar was considered satisfactory. Using high performance mortar to make masonry walls would cost $11 \%$ more than using conventional mortar.

Keywords: high performance mortar, masonry houses, brick walls in buildings.
\end{abstract}

\section{Introduction}

On March 20, 2012 an earthquake 7.4 on the Richter scale was felt in Mexico City with many aftershocks, fortunately no major damages were suffer, this reminded us of the devastation left by the 8.0 earthquake that occurred in 1985 . This work describes an initial effort to do some research on the development of a better performance masonry, the need exists to alleviate in some way the damages produced by earthquakes on conventional constructions, were little attention is given to the mortars used. Low income houses and small buildings 
are abundant in seismic areas and become in many cases seriously damaged when earthquakes strike.

\section{Materials}

Two types of mortars were used in this work, one designated as conventional mortar (CM) and one designated as high performance mortar (HPM), both included a Portland cement designated as CPC30R that complies with a Mexican standard, this is basically cement with 50 to $90 \%$ clinker plus gypsum and the rest includes other proper additions. The sand used in all the mixes was a crushed limestone that complies with ASTM C33 and its fineness modulus was 2.72.

The high performance mortar also included silica fume, polypropylene fibres and a superplasticizer admixture.

The type of brick used for making small masonry sections in this work is shown in figure 1, this is a common piece for construction and complies with the Mexican standard for such application, table 1 shows its physical characteristics.

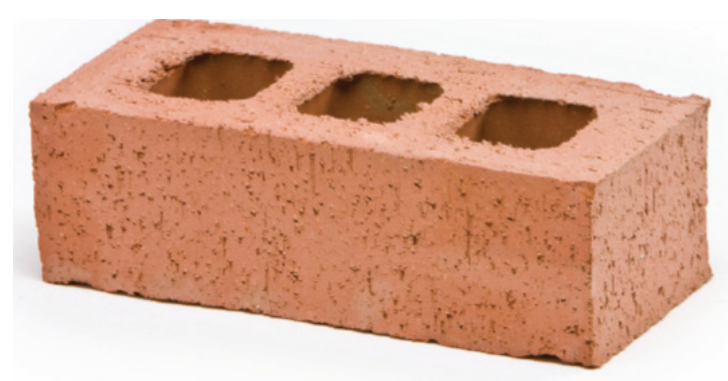

Figure 1: $\quad$ Typical clay brick.

Table 1: $\quad$ Physical brick characteristics.

\begin{tabular}{|c|c|}
\hline Characteristic & Measure \\
\hline Depth & $60 \mathrm{~mm}$ \\
\hline Width & $90 \mathrm{~mm}$ \\
\hline Length & $200 \mathrm{~mm}$ \\
\hline Weight per unit & $1.40 \mathrm{~kg}$ \\
\hline Units per m ${ }^{2}$ & 68 \\
\hline Water absorption & $9.4 \%$ \\
\hline
\end{tabular}


It was necessary to set a group of basic performance requirements for the high performance mortar, in order to distinguish it from the usual requirements specified by the Complementary Technical Norms for Design and Construction of Masonry Structures in Mexico City (CTNM) [1]. Consideration was given to literature review and common practices in setting up table 2. CTNM does not specify any requirement on consistency of the mortar but indicates that the amount of water should be enough to get a workable mix, it suggests that the mortar should include one part of cement and not less than 2.25 parts of sand but no more than 3 parts of sand by volume.

Table 2: $\quad$ Performance requirements for high performance mortar.

\begin{tabular}{|c|c|c|}
\hline Characteristic & $\begin{array}{c}\text { Performance } \\
\text { requirement }\end{array}$ & Norm requirement CTNM \\
\hline $\begin{array}{c}\text { Compressive } \\
\text { strength }\end{array}$ & $\geq 49 \mathrm{MPa}$ & $\geq 3.93 \mathrm{MPa}$ \\
\hline Flexural strength & $\geq 9.81 \mathrm{MPa}$ & none \\
\hline$\%$ Flow & $110 \pm 5 \%$ & none \\
\hline
\end{tabular}

\section{Experimental work to obtain HPM}

The methodology to obtain the best high performance mortar is based on research carried out by the Transportation Research Board as part of the National Cooperative Highway Research Program (NCHRP), particularly "NCHRP Project 18-08A, Supplementary Cementitious Materials to Enhance Durability of Concrete Bridge Decks" [2].

\subsection{Statistical design of the experiment}

The experiment considers the basic requirements from table 2 as responses, they are: compressive strength obtained from cubes (ASTM C109-08), flexural strength obtained from beams (ASTM C348-08) and flow of mortar (ASTM C1437-07). Valuable help was obtained from the software Statistical Experimental Design for Optimizing Concrete (SEDOC) [3], in setting up a fractional orthogonal design of the experiment and a final selection of the best HPM with basis on an overall function of "Desirability".

\subsubsection{Factors and levels}

With base on initial trials, personal experience and recommendations from literature review the factors and levels chosen are shown in table 3. It should be mentioned that the amount of fibres considered in al mixes was fixed to 3000 grams per cubic meter of mortar. 
Table 3: $\quad$ Factors and levels of the statistical design of experiment.

\begin{tabular}{|c|c|c|c|c|c|}
\hline $\begin{array}{c}\text { Factor } \\
\text { number }\end{array}$ & Factor name & Factor type & Level 1 & Level 2 & Level 3 \\
\hline 1 & $\begin{array}{c}\text { Amount of } \\
\text { water }\left(\mathrm{dm}^{3} / \mathrm{m}^{3}\right)\end{array}$ & Quantitative & 230 & 250 & 270 \\
\hline 2 & Silica Fume (\%) & Quantitative & 0 & 5 & 10 \\
\hline 3 & $\begin{array}{c}\text { Superplasticizer } \\
(\%)\end{array}$ & Quantitative & 0 & 0.5 & 1 \\
\hline 4 & w/cm & Quantitative & 0.35 & 0.40 & - \\
\hline
\end{tabular}

\subsubsection{Design matrix suggested by SEDOC}

Factors and levels of table 3 were introduced to SEDOC analysis program which handled the unbalanced arrangement of the experiment, table 4 indicates what is called the correspondent matrix of design.

Table 4: $\quad$ Design matrix obtained from SEDOC analysis.

\begin{tabular}{|c|c|c|c|c|}
\hline Mixture & $\begin{array}{c}\text { Factor1 } \\
\text { Amount of } \\
\text { water }\left(\mathrm{dm}^{3} / \mathrm{m}^{3}\right)\end{array}$ & $\begin{array}{c}\text { Factor 2 } \\
\text { Silica } \\
\text { fume (\%) }\end{array}$ & $\begin{array}{c}\text { Factor 3 } \\
\text { Superplasticizer } \\
(\%)\end{array}$ & $\begin{array}{c}\text { Factor 4 } \\
\mathrm{w} / \mathrm{cm}\end{array}$ \\
\hline $\begin{array}{c}\text { Control } \\
\text { Mixture }\end{array}$ & 270 & 0 & 0.0 & 0.35 \\
\hline Mixture \#1 & 230 & 0 & 0.0 & 0.40 \\
\hline Mixture \#2 & 230 & 5 & 0.5 & 0.35 \\
\hline Mixture \#3 & 230 & 10 & 1.0 & 0.35 \\
\hline Mixture \#4 & 250 & 0 & 0.5 & 0.35 \\
\hline Mixture \#5 & 250 & 5 & 1.0 & 0.40 \\
\hline Mixture \#6 & 250 & 10 & 0.0 & 0.35 \\
\hline Mixture \#7 & 270 & 0 & 1.0 & 0.35 \\
\hline Mixture \#8 & 270 & 5 & 0.0 & 0.35 \\
\hline Mixture \#9 & 270 & 10 & 0.5 & 0.40 \\
\hline
\end{tabular}

\subsubsection{Mix proportions}

Mix proportions for all of the mortar ingredients were obtained with a method by absolute volumes suggested by Aitcin [4]. Table 5 shows the proportions for each of the ten mortar mixes.

\subsubsection{Testing the mortars designed}

All the mixes designed were subject to three basic tests, namely flow, compressive strength and flexural strength, strength was checked at different ages. The results are presented in figures 2, 3 and 4 . 
Table 5: $\quad$ Mix proportions for mortars, $\mathrm{kg} / \mathrm{m}^{3}$ (except $\mathrm{dm}^{3} / \mathrm{m}^{3}$ for water).

\begin{tabular}{|c|c|c|c|c|c|c|}
\hline Mixture & Water & Cement & $\begin{array}{c}\text { Silica } \\
\text { fume }\end{array}$ & $\begin{array}{c}\text { Fine } \\
\text { aggregate }\end{array}$ & Superplaticizer & Fibres \\
\hline Control & 287.60 & 771.43 & 0.00 & 1204.46 & 0.00 & 0.00 \\
\hline M1 & 251.56 & 575.00 & 0.00 & 1475.56 & 0.00 & 3.00 \\
\hline M2 & 248.37 & 624.29 & 32.86 & 1392.01 & 3.04 & 3.00 \\
\hline M3 & 246.19 & 591.43 & 65.71 & 1378.30 & 6.08 & 3.00 \\
\hline M4 & 266.88 & 714.29 & 0.00 & 1302.06 & 3.31 & 3.00 \\
\hline M5 & 266.20 & 593.75 & 31.25 & 1365.32 & 5.79 & 3.00 \\
\hline M6 & 268.72 & 642.86 & 71.43 & 1281.34 & 0.00 & 3.00 \\
\hline M7 & 282.87 & 771.43 & 0.00 & 1197.91 & 7.14 & 3.00 \\
\hline M8 & 287.41 & 732.86 & 38.57 & 1191.64 & 0.00 & 3.00 \\
\hline M9 & 286.40 & 607.50 & 67.50 & 1261.15 & 3.13 & 3.00 \\
\hline
\end{tabular}

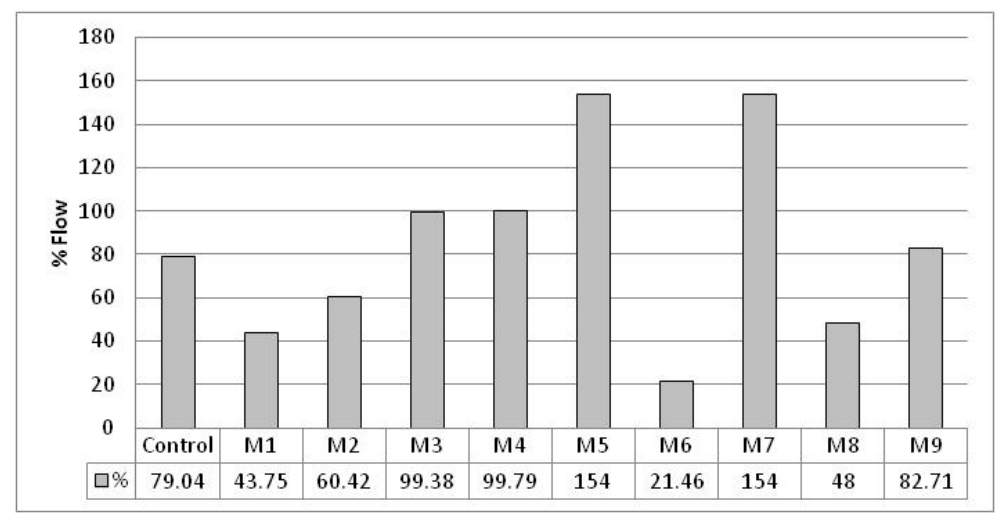

Figure 2: $\quad$ Fresh mortar consistency.

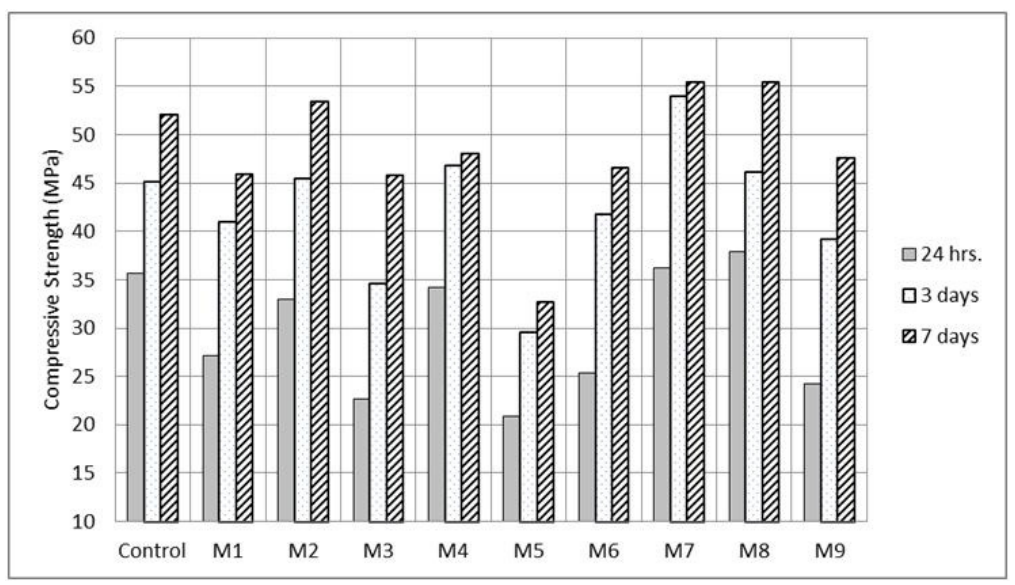

Figure 3: Compressive strength. 


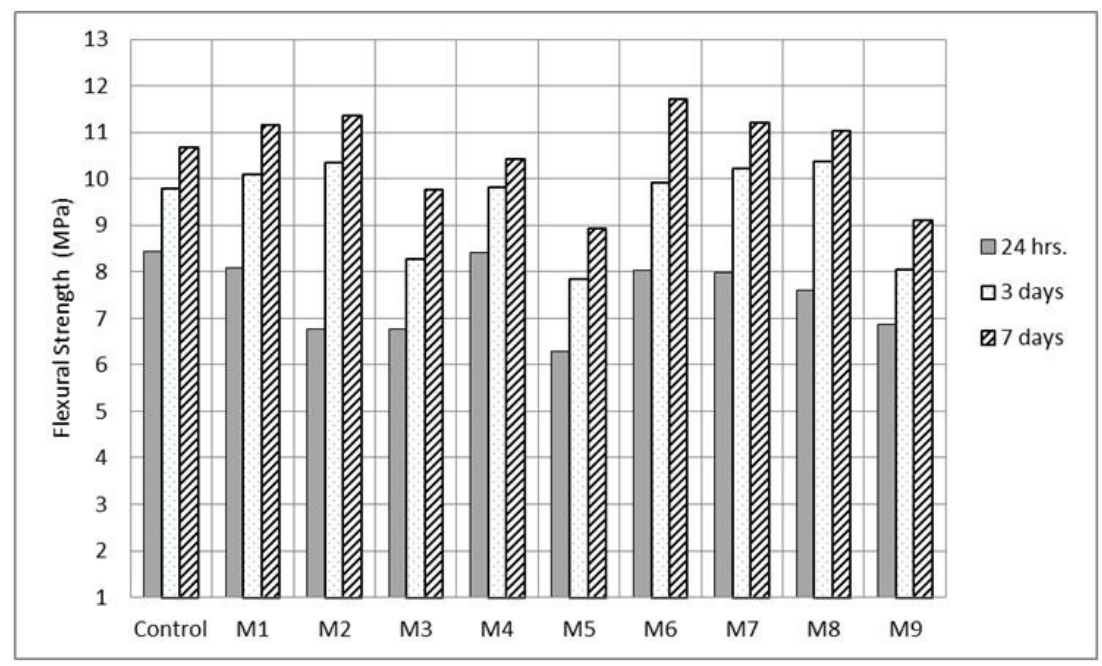

Figure 4: $\quad$ Flexural strength.

Table 6: $\quad$ Best mixture obtained from SEDOC analysis.

\begin{tabular}{|c|c|c|c|c|c|}
\hline & $\begin{array}{c}\text { Water } \\
\left(\mathrm{dm}^{3} / \mathrm{m}^{3}\right)\end{array}$ & $\begin{array}{c}\text { Silica } \\
\text { fume } \\
(\%)\end{array}$ & $\begin{array}{c}\text { Superplasticizer } \\
(\%)\end{array}$ & w/cm & $\begin{array}{c}\text { Global } \\
\text { desirability }\end{array}$ \\
\hline BTM & 250 & 0 & 0.5 & 0.35 & 0.911 \\
\hline BPM & 270 & 0 & 0.5 & 0.35 & 0.992 \\
\hline
\end{tabular}

Table 7: Confirmation tests results (average).

\begin{tabular}{|c|c|c|c|c|}
\hline Mixture & \% Flow & $\begin{array}{c}\text { Compressive } \\
\text { strength (MPa) }\end{array}$ & $\begin{array}{c}\text { Flexural } \\
\text { strength } \\
(\mathrm{MPa})\end{array}$ & $\begin{array}{c}\text { Global } \\
\text { desirability }\end{array}$ \\
\hline BTM & 101.25 & 47.14 & 10.44 & \multirow{2}{*}{0.920} \\
\hline Desirability & 0.900 & 0.908 & 0.955 & \multirow{2}{*}{0.971} \\
\hline BPM & 120 & 52.12 & 10.48 & \\
\hline Desirability & 0.980 & 0.975 & 0.956 & \\
\hline
\end{tabular}

Table 7 also shows the best predicted mortar as BPM out of 5184 different possible mixes, the global desirability for this mix is 0.992 . Notice that no silica fume was included in the final mix, this influenced most likely for the time constraint in the experiment.

\subsubsection{Confirmation analysis}

The final step in finding the high performance mortar for the study consists in making and testing the mixes indicated in table 7, namely BTM and BPM. Hence

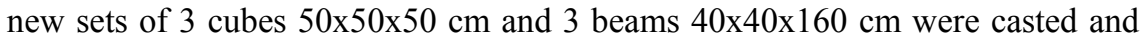
tested for each mix at 7 days of age. Table 8 shows the results, from here it can 
be confirmed that the best mix and therefore selected as HPM is the mix designated as BPM because its higher overall desirability value of 0.971 .

Table 8: $\quad$ Compressive strength of masonry prisms constructed with CM.

\begin{tabular}{|c|c|c|c|c|c|}
\hline Prism & $\begin{array}{c}\text { Area } \\
\left(\mathrm{mm}^{2}\right)\end{array}$ & $\mathrm{Pu}(\mathrm{N})$ & Height/Width & $\begin{array}{c}\text { Slenderness } \\
\text { correction }\end{array}$ & $\begin{array}{c}f m \\
(\mathrm{MPa})\end{array}$ \\
\hline 1 & 17,836 & 155,750 & 3.54 & 0.954 & 8.35 \\
\hline 2 & 17,745 & 58,418 & 3.52 & 0.952 & 3.12 \\
\hline 3 & 17,940 & 88,711 & 3.43 & 0.943 & 4.67 \\
\hline 4 & 18,032 & 164,272 & 3.49 & 0.949 & 8.70 \\
\hline 5 & 17,940 & 112,110 & 3.49 & 0.94 & 5.91 \\
\hline 6 & 17,940 & 197,242 & 3.51 & 0.951 & 10.47 \\
\hline
\end{tabular}

\subsection{Testing masonry sections}

Small masonry sections were fabricated considering two different mortar mixes, one designated as conventional ( $\mathrm{CM}$, proportions $1: 3$ by volume) and the other designated as HPM which comes from previous analysis. It was decided that both mortars should have the same consistency, so in order to compensate for brick absorption flow was set at $126.3 \%$. Tables 9 and 10 show results in compression of masonry prisms for each type of mortar indicated.

Table 9: $\quad$ Compressive strength of masonry prisms constructed with HPM.

\begin{tabular}{|c|c|c|c|c|c|}
\hline Prism & $\begin{array}{c}\text { Area } \\
\left(\mathrm{mm}^{2}\right)\end{array}$ & $\mathrm{Pu}(\mathrm{N})$ & Height/Width & $\begin{array}{c}\text { Slenderness } \\
\text { correction }\end{array}$ & fm $(\mathrm{MPa})$ \\
\hline 7 & 17,940 & 176,814 & 3.44 & 0.944 & 9.36 \\
\hline 8 & 17,836 & 120,642 & 3.57 & 0.957 & 6.45 \\
\hline 9 & 18,032 & 86,730 & 3.45 & 0.945 & 4.56 \\
\hline 10 & 17,940 & 139,818 & 3.58 & 0.958 & 7.44 \\
\hline 11 & 17,836 & 174,461 & 3.56 & 0.956 & 9.30 \\
\hline 12 & 17,745 & 129,497 & 3.56 & 0.956 & 6.93 \\
\hline
\end{tabular}

Table 10: $\quad$ Shear strength for masonry assemblages with CM.

\begin{tabular}{|c|c|c|c|c|c|}
\hline Prism & $\begin{array}{c}\text { Area } \\
\left(\mathrm{mm}^{2}\right)\end{array}$ & $\mathrm{Pu}(\mathrm{N})$ & Height/Width & $\begin{array}{c}\text { Slenderness } \\
\text { correction }\end{array}$ & $f m(\mathrm{MPa})$ \\
\hline 7 & 17,940 & 176,814 & 3.44 & 0.944 & 9.36 \\
\hline 8 & 17,836 & 120,642 & 3.57 & 0.957 & 6.45 \\
\hline 9 & 18,032 & 86,730 & 3.45 & 0.945 & 4.56 \\
\hline 10 & 17,940 & 139,818 & 3.58 & 0.958 & 7.44 \\
\hline 11 & 17,836 & 174,461 & 3.56 & 0.956 & 9.30 \\
\hline 12 & 17,745 & 129,497 & 3.56 & 0.956 & 6.93 \\
\hline
\end{tabular}


Figure 5 shows a typical failure of conventional masonry while figure 6 shows a failure of HPM masonry.
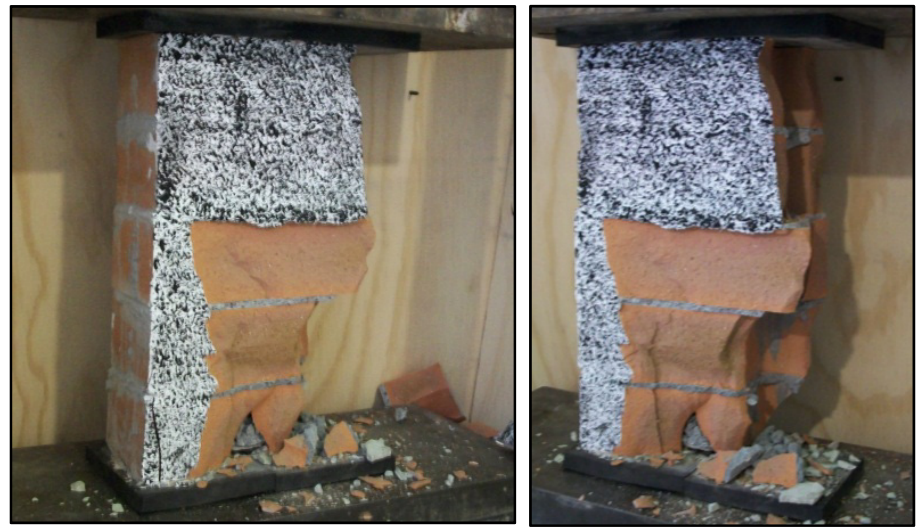

Figure 5: Failure of masonry prism constructed with conventional mortar.

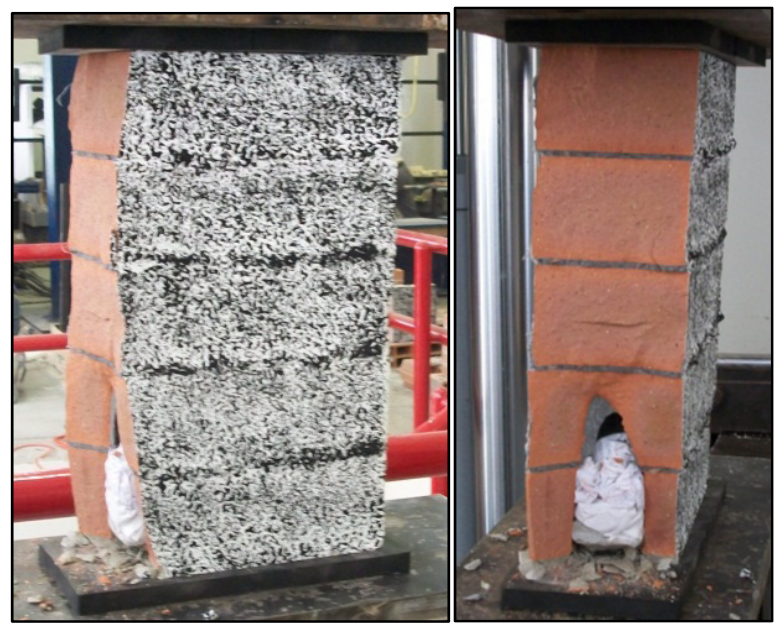

Figure 6: Failure of masonry prism constructed with high performance mortar.

Table 11 shows shear strength results of conventional masonry assemblages subjected to diagonal compression. Table 12 shows shear strength results of HPM assemblages under diagonal compression. 
Table 11: $\quad$ Shear strength for masonry assemblages with HPM.

\begin{tabular}{|c|c|c|c|c|c|c|}
\hline \multirow{2}{*}{ Assemblages } & \multicolumn{2}{|c|}{ Average (mm.) } & \multirow{2}{*}{ Coefficient } & \multirow{2}{*}{$\begin{array}{c}\text { Area } \\
\left(\mathrm{mm}^{2}\right)\end{array}$} & \multirow{2}{*}{$\mathrm{Pu}(\mathrm{N})$} & \multirow{2}{*}{$\begin{array}{c}V \\
(\mathrm{MPa})\end{array}$} \\
\hline & Height & Width & & & & \\
\hline 1 & 327 & 296 & 0.91 & 40,358 & 40,462 & 1.00 \\
\hline 2 & 325 & 295 & 0.91 & 40,161 & 38,521 & 0.96 \\
\hline 3 & 325.5 & 296 & 0.91 & 40,256 & 42,826 & 1.06 \\
\hline 4 & 326 & 296 & 0.91 & 40,290 & 39,295 & 0.98 \\
\hline 5 & 326 & 297 & 0.91 & 40,352 & 49,798 & 1.23 \\
\hline 6 & 326 & 296 & 0.91 & 40,290 & 37,138 & 0.92 \\
\hline & & & & & Average & 1.00 \\
\hline
\end{tabular}

Table 12: $\quad$ Shear strength for masonry assemblages with HPM.

\begin{tabular}{|c|c|c|c|c|c|c|}
\hline \multirow{2}{*}{ Assemblages } & \multicolumn{2}{|c|}{ Average (mm.) } & \multirow{2}{*}{ Coefficient } & \multirow{2}{*}{$\begin{array}{c}\text { Area } \\
\left(\mathrm{mm}^{2}\right)\end{array}$} & \multirow{2}{*}{$\mathrm{Pu}(\mathrm{N})$} & \multirow{2}{*}{$\begin{array}{c}V \\
(\mathrm{MPa})\end{array}$} \\
\hline & Height & Width & & & & \\
\hline 7 & 322 & 294 & 0.91 & 39,896 & 43,198 & 1.08 \\
\hline 8 & 320 & 295 & 0.92 & 39,824 & 43,296 & 1.09 \\
\hline 9 & 320 & 295 & 0.92 & 39,824 & 47,611 & 1.19 \\
\hline 10 & 321 & 295 & 0.92 & 39,891 & 44,443 & 1.11 \\
\hline 11 & 319 & 295 & 0.92 & 39,756 & 47,111 & 1.18 \\
\hline 12 & 320 & 295 & 0.92 & 39,824 & 41,963 & 1.05 \\
\hline & & & & & Average & 1.12 \\
\hline
\end{tabular}

Figure 7 shows a typical failure of conventional masonry assemblage on the left and assemblage with HPM on the right. 


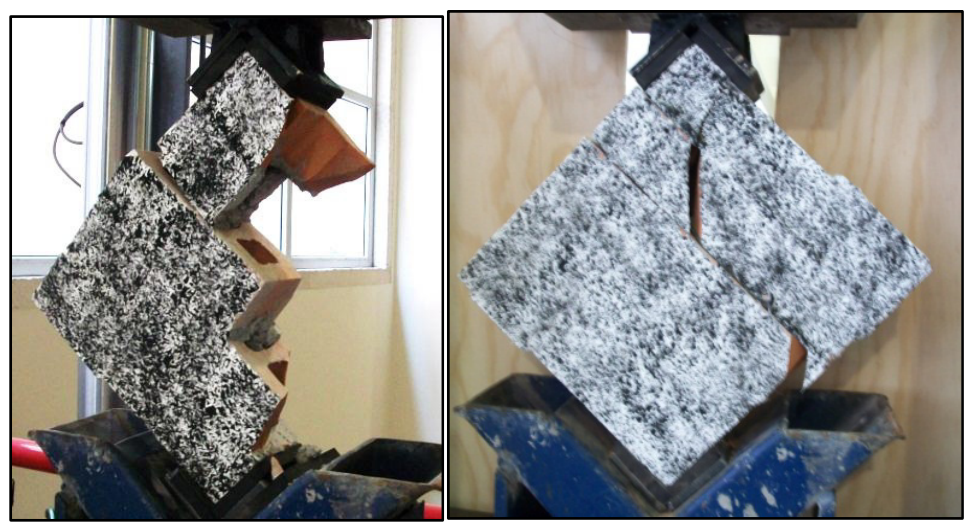

Figure 7: Failure of masonry assemblages, conventional mortar on the left, HPM used on the right.

As it can be seen from the pictures of the masonry sections tested, specimens were painted to obtain during testing correlated digital images with the software Vic-2D [5], images were valuable in helping to register a history of deformations and mode of failure. This technique was used also in calculating the modulus of elasticity and the modulus of rigidity of the masonry.

\section{Discussion}

Results obtained when comparing the performance of conventional mortar against the high performance mortar, as well as comparing their participation in masonry evaluation can be summarized in table 13 .

Table 13: $\quad$ Summary of findings.

\begin{tabular}{|c|c|c|}
\hline Material & Characteristic & Improvement with HPM \\
\hline \multirow{2}{*}{$\sum^{*}$} & Compressive Strength & $62.5 \%$ \\
\cline { 2 - 3 } & Flexural Strength & $26.9 \%$ \\
\cline { 2 - 3 } & Compressive Strength & $34.7 \%$ \\
\cline { 2 - 3 } & Modulus of elasticity & $7.80 \%$ \\
\cline { 2 - 3 } & Shear Strength & $12.5 \%$ \\
\cline { 2 - 3 } & Modulus of Rigidity & $78.6 \%$ \\
\hline
\end{tabular}


As it can be seen from table 13, HPM contributes to develop superior mechanical properties as compared to conventional mortar, in this case a typical mortar suggested by a norm that applies to masonry constructions in Mexico City. However because HPM includes a superplasticizer caution in handling this mortar should be encouraged since this mortar tends to flow more in time, therefore timing in building the masonry is important.

What can we expect from seismic demand on masonry made with HPM? Initially and as a result of static testing on the small masonry sections, it was observed that most of the masonry sections made with conventional mortar tend to show an explosive mode of failure, while HPM masonries tend to show an implosive mode of failure. This suggests that adding fibers helped to hold longer before failing.

In order to check theoretically about the differences in behavior considering both the HPM masonry and conventional masonry, a three story building was subjected to seismic forces. A basic architectural design for masonry walls with hollow bricks and monolithic slabs on top of them was considered, and then a simplified seismic analysis was carried out for each case as per the Complementary Technical Norms for Design under seism in Mexico City (CTNM). From the results shown in Table 14, it can be concluded that resistant forces on directions $\mathrm{x}$ and $\mathrm{y}$ are better than acting forces due to seism only if HPM is used on the masonry walls of the first floor.

Table 14: Acting and resistant forces for a first floor of a small building.

\begin{tabular}{|c|c|c|c|}
\hline Direction & $\begin{array}{c}\text { Acting force } \\
\text { Due to seism, } \mathrm{kN}\end{array}$ & $\begin{array}{c}\text { Resistant force } \\
\text { Conventional } \\
\text { mortar, } \mathrm{kN}\end{array}$ & $\begin{array}{c}\text { Resistant force } \\
\text { HPM, } \mathrm{kN}\end{array}$ \\
\hline $\mathrm{X}$ & 447.18 & 431.88 & 469.54 \\
\hline $\mathrm{Y}$ & 437.37 & 457.18 & 508.82 \\
\hline
\end{tabular}

As far as cost is concern, a straightforward analysis considering basic and non specialized labour yielded an $11 \%$ higher cost for masonry walls using HPM, however the benefits are still to be accounted for when using this alternative in construction.

\section{Conclusion}

Building houses and small buildings with brick masonries is and will be a very common way of construction in Mexico City and many other cities elsewhere, and it is believed that using HPM in this kind of construction may help to reduce the damages that people may suffer when earthquakes strike in seismic areas. 


\section{References}

[1] NTC. NTC-Normas Técnicas Complementarias para Diseño y Construcción de Estructuras de Mampostería. México: Gaceta Oficial del Distrito Federal, 2004.

[2] NCHRP. Report 566: Guidelines for Concrete Mixtures Containing Supplementary Cementitious Materials to Enhance Durability of Bridge Decks. Washington D. C.: Transportation Research Board, 2007.

[3] The Statistical Experimental Design for Optimizing Concrete (SEDOC), www.trb.org/Main/Public/Blurbs/158851.aspx

[4] Aïtsin, P-C. High-Performance Concrete. London: E\&FN SPON, 2004.

[5] Cintrón, R. and Saouma, V. Strain Measurements with the Digital Image Correlation System Vic-2D. Department of Civil Environmental and Architectural Engineering, University of Colorado. Boulder: s. n., 2008. 